\title{
Neighborhood Effects, Disturbance Severity, and Community Stability in Forests
}

\author{
Lee E. Frelich* and Peter B. Reich
}

Department of Forest Resources, University of Minnesota, 1530 North Cleveland Avenue, St. Paul, Minnesota 55108, USA

\begin{abstract}
A bstract
A theoretical framework and conceptual model for temporal stability of forest tree-species composition was developed based on a synthesis of existing studies. The model pertains primarily to time periods of several tree lifetimes (several hundred to a few thousand years) at the neighborhood and stand spatial scales (0.01-10 ha), although a few extensions to the landscape scale are also made. The cusp catastrophe was chosen to illustrate compositional dynamics at the stand level for jack pine, northern hardwood, and white pine forests in the Great Lakes Region of the United States and for tropical rainforests in the northern Amazon basin. The models feature a response surface (degree of dominance by late-successional species) that depends on two variables: type of neighborhood effects of the dominant tree species and severity of disturbances. Neighborhood effects are processes that affect the chance of a species replacing itself at the time of disturbance (they can be positive, neutral, or negative) and are
\end{abstract}

\section{INTRODUCTION}

The notion that forests at the stand level are compositionally stable for several generations of trees (several hundred to a few thousand years) has been challenged by many ecologists. Continuous successional change due to frequent disturbance, climate change, canopy-nutrient feedbacks, or chanceevents

Received 23 J une 1998; accepted 16 December 1998.

*Corresponding author, e-mail: freli001@maroon.tc.umn.edu of two types: overstory-undestory effects, such as the presence of advanced reproduction; and disturbance-activated effects, such as serotinous seed rain. Disturbance severity is the proportion of trees killed during a disturbance. Interactions between neighborhood effects and disturbance severity can lead to either punctuated stability (dramatic but infrequent change in composition, in those forests dominated by species with positive neighborhood effects) or succession (continuous change, in those forests dominated by species with neutral-negative neighborhood effects). We propose that neighborhood effects are a major organizing factor in forest dynamics that provide a link across spatial scales between individual trees and disturbance/patch dynamics at the stand and landscape scales.

Key words: community stability; disturbance severity; neighborhood effects; punctuated stability; succession. such as local extinction and immigration are among the reasons the stable equilibrium hypothesis has been opposed (Heinselman 1981; Davis 1986; Foster and King 1986; Hubbell and Foster 1986). In contrast, others point out that forests dominated by shade-tolerant species appear to be self-replacing, although acknowledging that rare catastrophic disturbances upset the temporary equilibrium (Clements 1936; Hough and Forbes 1943; Lorimer 1977). From yet another perspective, some also point out cases where canopy-killing disturbances cause great 
changes in biomass and nutrient status of an ecosystem, but the species composition of the subsequent canopy remains similar to that before the disturbance (Dix and Swan 1971; Heinselman 1973; J ohnson and Fryer 1989). Such examples bring into question the idea that compositional succession necessarily follows canopy-killing disturbance.

There are no simple ways of reconciling these apparent empirical and conceptual discrepancies. In this report, we propose a conceptual model that can simultaneously encompass and incorporate these seemingly disparate patterns. This model is based on the idea that vegetation state (that is, forest composition) can be explained as a nonlinear function of disturbance severity and the strength of the neighborhood (feedback) effects of the dominant tree species. In so doing, we propose that neighborhood effects produced by canopy trees are a major organizing factor in the spatial and temporal dynamics of some forest types. N eighborhood effects in forests are defined as any process mediated by canopy trees that affects the replacement probability by the same or other species at the time of canopy mortality. We define neighborhood effects in relation to dominant tree species or groups of species. Positive neighborhood effects (analogous to feedback effects) are processes that promote self-replacement, negative effects are processes that deter self-replacement (unless no other species are available), and neutral effects are processes that neither favor nor disfavor self-replacement. In general, neighborhood effects may include seed rain, shading, stump and root sprouting, and alteration of the forest floor physical or nutrient status to favor or disfavor germination and establishment of a given species. We previously identified two types of neighborhood effects in study sites in the Great Lakes Region of North America (Frelich and Reich 1995a). The first type are overstory-understory effects, which can be positive or negative and operate by influencing the species composition of seedlings and saplings underneath canopy trees, which in turn may translate into influence on the species of the tree(s) that replace a canopy tree when it dies. The second type of neighborhood effects-disturbance-activated effects-operate mainly in forests perpetuated by intense fire where seedlings are mostly killed at the same time as the canopy trees. Serotinous seed rain and sprouting from underground rootstocks are among the mechanisms that influence the chance of a given species replacing itself at the time of a canopy-killing disturbance.
A topological model in mathematics, known as catastrophe theory, helps explain the dynamics of many systems in the physical and social sciences that have both stable and unstable behaviors (Thom 1975; Zeeman 1976). Ecologists have used catastrophe theory to explain or describe sudden changes in populations or ecosystem parameters such as productivity (Gatto and Rinaldi 1987; Loehle 1989). J ones (1977) and Holling (1981) were among the first to use the model to describe long-term successional dynamics of forests and applied it to systems where insect infestations periodically kill the canopy in boreal forests and where fire regulates the balance between forest and grassland.

Here we develop the model qualitatively to illustrate our hypothesis about how interactions between disturbances, especially wind and fire, and biological features of forest communities affect longterm stability of composition in a variety of forest types. Then we use semiquantitative data for the one forest type for which we have the most data, to show that field observations conform to the proposed cusp model. The mathematical details of the model are presented in a recent synthesis of the subject by Ludwig and colleagues (1997). We find catastrophe theory useful because it allows us to build a single descriptive, conceptual model for one or many forest ecosystem(s) that feature(s) continuous and discontinuous change. The theory is used to extend the neighborhood effect hypothesis of forest dynamics from a previous report (Frelich and Reich 1995a). Forests with strong positive neighborhood effects should be stable with rare jumps in composition, whereas those with strong negative neighborhood effects should change continuously and unidirectionally, and those with neutral neighborhood effects appear unstable and "wander" over time. Our perception of the stability of a forest may differ dramatically at different spatial and temporal scales, so it is necessary to define the scale(s) at which a given analysis is believed to be valid (Schoonmaker and Foster 1991). We will examine stability under natural disturbance regimes that were in effect in the Great Lakes Region prior to extensive European settlement (1650-1900) and until the present time in the northern Amazon, as well as how stability may shift under the modern human-dominated disturbance regime. Spatial scales examined will mostly be the neighborhood [0.001-0.1 ha (Frelich and others 1998)] and stand levels (1-10 ha), although we make some extensions to the landscape level. The time scale examined will up to 3000 years. Regional assemblages of tree species in the forests used as examples here, including species 
from all successional stages, hold together for periods of a few thousand years (Davis 1981; Webb 1987). Therefore, the disturbance dynamics and interactions among species within this length of time are of interest.

For clarity, types of changes at the stand level covered by this report are as follows. When examining compositional dynamics, we follow the most common definition of succession as directional change in composition over time, implying that one species or group of species is replacing another. A sudden replacement of one species or group of species in a stand at the time of a severe disturbance, which generally initiates an episode of succession, is here called a compositional catastrophe (Frelich and Reich 1995a). Shifts in relative abundance of $25 \%$ or more among an existing group of species, or the removal of one species from a multispecies complex, will be referred to as a major fluctuation (for example, the ratio of pine to birch changes from $75 \%: 25 \%$ to 25\%:75\% after a disturbance). Smaller shifts in relative abundance caused by disturbance (for instance, the ratio of pine-birch changes from $60 \%$ : $40 \%$ to $40 \%: 60 \%$ ) are referred to as minor fluctuations. Note that disturbances of such high severity that primary succession is initiated (for example, landslides, volcanic eruptions, or glaciation), and disturbances that regulate the forest-grassland interface, are beyond the scope of the report. Here we are examining changes among forest types, not changes from forest to nonforest. We are al so mostly limiting this report to changes in forest canopy composition, rather than other ecosystem parameters like productivity, age structure, and understory plant communities.

The specific objectives of this article are

1. Provide a conceptual model of forest dynamics that uses the cusp catastrophe as an illustrative tool. Our strategy is to provide the best model possible at this time and prompt others to evaluate its applicability in other forests or suggest alternative explanations for the data. A conceptual model can display early results from ongoing research and guide continuing research.

2. Show how neighborhood effects and disturbance severity may influence compositional stability over both time and space. We show that stability and continuous change in composition both occur and are explained by different combinations of the same variables. Also, neighborhood effects provide a linkage between individual trees and dynamics at the neighborhood, stand, and landscape scales.

\section{A Conceptual Model of Forest DYNAMICS}

\section{Structure of the Model}

The cusp catastrophe (Figure 1) is suitable for systems with two important control variables (Zeeman 1976). The control variables influence a response surface that represents some measure of a dependent variable, in this case degree of dominance by late-successional species.

Control variable 1 is a gradient of disturbance severity. We use a working definition wherein disturbance severity is simply the proportion of trees (both mature and advanced reproduction) killed during a disturbance episode [see Oliver and Larson (1990)]. Low-severity disturbances kill small parts of either the overstory and/or understory (for example, individual or small-group treefalls). Moderate-severity disturbances kill most of one forest layer, either the understory with its advanced regeneration and/or seedbank (surface fires) or the overstory (heavy windthrow), while leaving the other layer mostly intact. High-severity disturbances kill both the understory and overstory (for example, intense fires). Forest clear-cutting by people represents a disturbance roughly akin in severity to heavy windfall or to canopy-killing fire if harvested sites are burned after cutting.

It is also important to examine the role of disturbance frequency that is implicit, although not obvious, in the model and the disturbance severity gradient. Two disturbances of moderate severity, or several of low severity, occuring within a few years may sometimes have the same effect as one moderate-severity or high-severity disturbance. For example, case studies of windstorm and cutting effects in the northern hardwoods show that several lowseverity disturbances within 1-2 decades can create stands with similar size structure and composition as stands that had complete canopy removal at one time (Erye and Zillgitt 1953; Frelich and Lorimer 1991), although two moderate-severity disturbances, such as total canopy blowdown, obviously cannot occur twice within a short time. It is important to consider whether the forest has sufficient time for recovery between disturbances; if the forest recovers to the predisturbance state after one disturbance, then a second disturbance of similar severity will not have any more impact than the first. If the second disturbance occurs shortly after the first, before recovery occurs, then in effect the severity of the two disturbances may be totally or partially additive. Referring to our previous definition of 


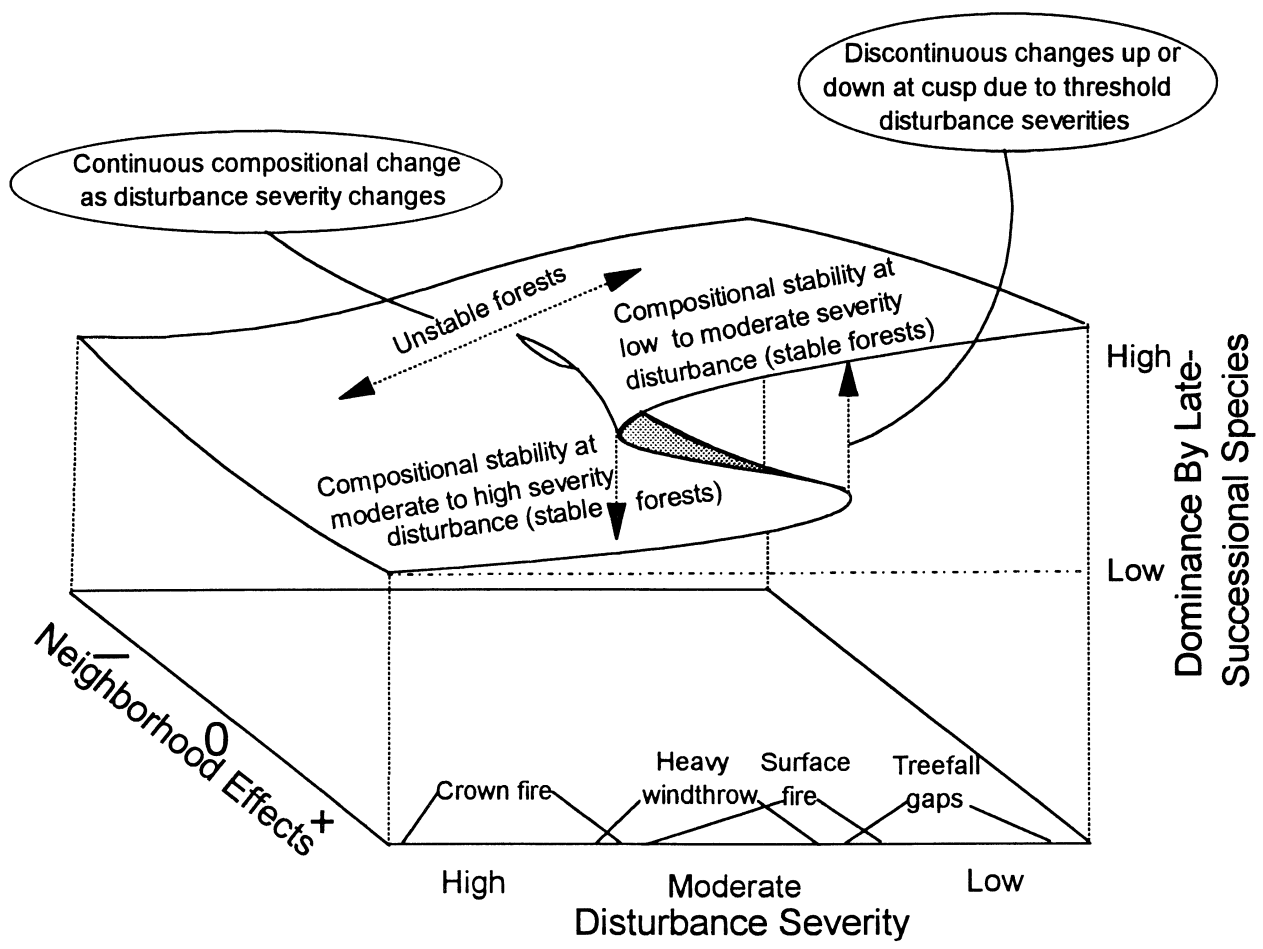

Figure 1. Generalized re sponse surface (or equilibrial attractor) of stand-level vegetation, based on the cuspcatastrophe model. Neighborhood effects exerted by the dominant species range from strong $(+)$, random $(0)$, and none $(-)$ in tendency for self-replacement. Ranges of severity represented for each disturbance type reflect experience in our study areas.

disturbance severity, we can see that any disturbance that results in a reduction in the number of mature trees and advanced reproduction to a level lower than that after the previous disturbance will have an additive effect to the previous disturbance.

A key to relating disturbance frequency and severity is the cumulative amount of disturbance received by a stand over time, and the impacts of those disturbances (Figure 2A). Some hypothetical examples of trajectories that individual stands may take in response to a sequence of disturbances that vary in timing and severity are shown in Figure 2B. Does disturbance occur at a high enough rate, as indicated by a steeply sloped threshold line in Figure 2 , to maintain a forest stand dominated by early successional species (that is, is disturbance rate higher than the lower, less steeply sloped line)? Or does disturbance occur at a low enough rate to allow maintenance of late-successional species (that is, is rate lower than the upper, more steeply sloped, line)?

Control variable 2-neighborhood effects exerted by the dominant species-range from negative (little or no likelihood of self-replacement at the time of a canopy tree death) along the back of the response surface to neutral (random chance of a species replacing itself) to highly positive (for instance, $>75 \%$ likelihood of self replacement) along the front (Figure 1).

The response surface (Figure 1) shows four features (Poston and Stewart 1978): (a) bimodality (above and below the cusp); (b) divergence in the neighborhood effect control variable; (c) hysteresis, or delayed response to changes in disturbanceregime severity in forests with positive neighborhood effects; and (d) sudden transitions caused by a small change in disturbance-regime severity at the edge of the cusp. These four properties manifest themselves topologically as the cusp in Figure 1. For an application of catastrophe theory to be valid, it must be shown that a cusp exists (Zeeman 1976; Poston and Stewart 1978); in other words, that alternative vegetation states exist for the same combination of control variables. This task is taken up in the case studies (see the next section).

The two control variables will sometimes change dramatically and/or abruptly, especially disturbance severity. Under these conditions, the response surface becomes an "equilibrial attractor" (Poston and Stewart 1978; Loehle 1989): because there may be a time lag in the response of the vegetation to a change in disturbance severity, the disturbance regime may not remain constant long enough for the vegetation to respond fully, and/or unique disturbance events may occur that are dramatically different in severity from those in the "normal" regime. The position of a given stand may be off (above or below) of the surface for variable periods (Figure 3). Stands dominated by species with positive neighborhood effects that existed under a low-severity disturbance regime may suddenly experience much more 


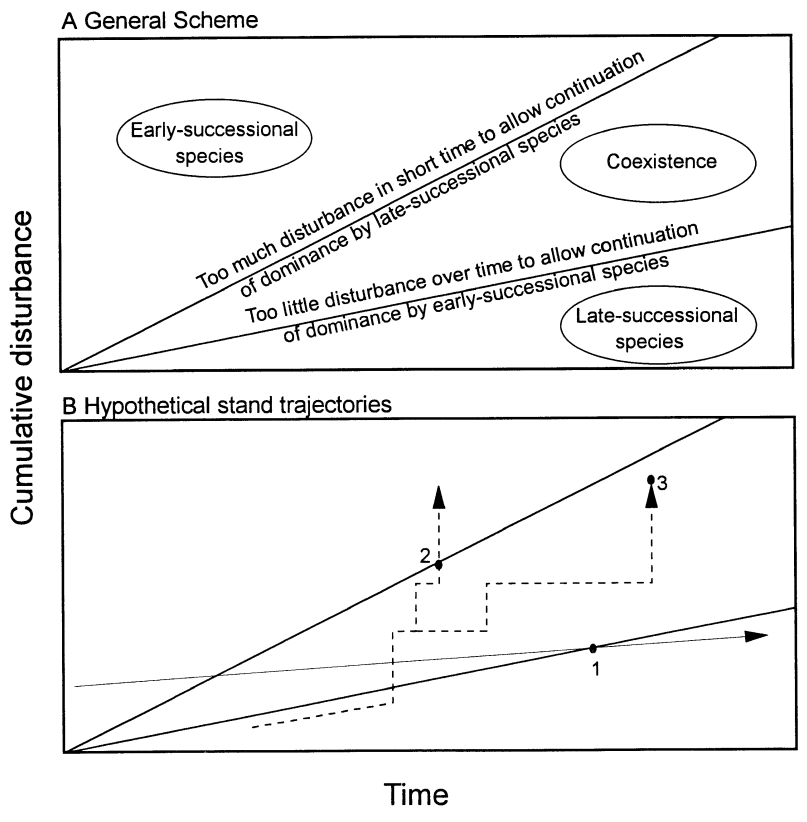

Figure 2. Cumulative disturbance in forest stands over time and successional state. A General scheme showing regions of high, moderate, and low rates of disturbance. The different slopes of the two lines represent different rates of disturbance, which in turn represent hypothetical thresholds for minimum rate of disturbance necessary to maintain early successional species (lower line) or maximum rate of disturbance allowed to maintain latesuccessional species (upper line). B Hypothetical trajectories of individual stands. The solid-line trajectory shows a case where the cumulative amount of disturbance over time is not sufficient to maintain early-successional species composition, and conversion to late-successional species occurs at point 1 . The dotted-line trajectory shows a case where three disturbances in a short time are sufficient to cause conversion from late-successional species to early-successional species at point 2 . If the same three disturbances occurred over a longer period, species conversion would not occur (point 3).

severe disturbance, causing a sudden jump from a position well to the right of the cusp to well to its left. In this case, where a compositional catastrophe occurs, most of the previously existing trees are killed by the disturbance, so that there is little time lag for the vegetation to come back to the equilibrial attractor (hence the dotted downward arrows indicating sudden change in Figure $3 \mathrm{~A}$ ).

Going the opposite direction, namely, an existing high-severity disturbance regime suddenly ends, and only low-to-moderate severity disturbances occur thereafter, a much longer time lag may occur. Trees of early-successional fire-adapted species may live for several decades while late-successional species slowly replace them, so that the stand slowly approaches the response surface-a process repre-

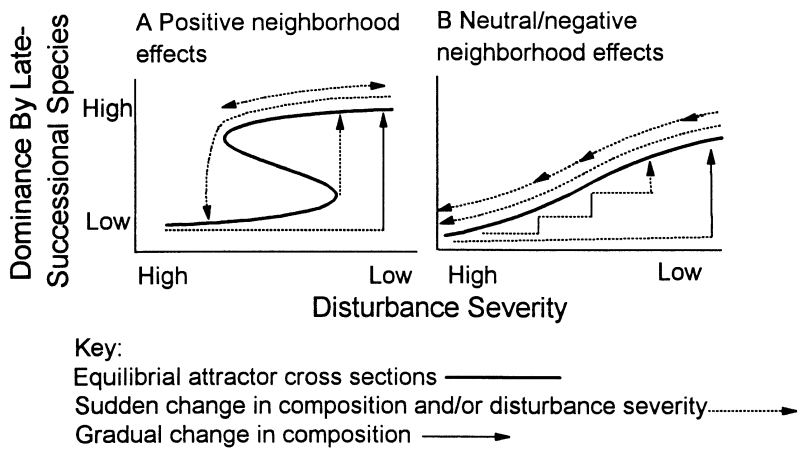

Figure 3. Movements stands make in relation to the equilibrial attractor as disturbance-regime severity changes over time. A given stand proceeds al ong solid-line segments (to the next arrowhead or the next change of line type) gradually, in successional processes, whereas a given stand proceeds along the entire length of dotted-line segments suddenly, in one jump. A Stands with positive neighborhood effects. B Stands with negative or neutral neighborhood effects.

sented by the solid upward-pointing arrow in Figure 3A. A sudden jump from dominance by earlysuccesisonal to late-successional species (upward dotted arrow in Figure 3A), known as disturbancemediated accelerated succession, can also occur when heavy canopy windthrow or logging releases advanced regeneration (Abrams and Scott 1989; Abrams and Nowacki 1992).

Also note that a given stand could experience a moderately large change in disturbance severity, in either direction, with little resulting change in composition, if the severity change does not span the cusp (for example, notethe double-ended arrow in Figure 3A).

In stands dominated by species with negative neighborhood effects, increasing disturbance severity may lead to a slide down the equilibrial attractor, with relatively little time lag, either all at once or in several stages (Figure 3B, multiple and single downward pointing arrows). Going from high-severity to low-severity disturbances, a delayed response is likely, because a given species is not likely to be removed quickly (that is, mature trees will not all be killed) by disturbances of lower severity than those that allowed establishment. In these cases, succession toward the equilibrial attractor may progress in several small steps or in one large step (Figure 3B, upward arrows) via previously mentioned processes of individual tree replacement in gaps or disturbancemediated accelerated succession.

The overall scenario for forests where frequency and severity of disturbances change suddenly over time may be summarized as follows. Time lags are 
likely to be short (a few years) when the type of disturbances suddenly changes from low to high severity, because severe disturbances (or additive disturbance combinations) tend to remove the existing trees and allow quick invasion by other species. On the other hand, changes from high-severity to low-severity disturbances are likely to leave a much more substantial legacy of trees whose adaptations are out of synch with the new disturbance regime. Thus, positions below the equilibrial attractor, on the right side of the diagram (Figure 1) in forests that are currently experiencing low-severity disturbance, are much more likely to occur than positions above the surface. Also, according to our model, changes in disturbance severity that span a large portion of the severity gradient in forests with positive neighborhood effects, starting from either the highest or lowest severity, are not likely to result in much vegetation change or time lag. Finally, hysteresis will occur in forests with all degrees of neighborhood effects, since the path when changing from low-severity to high-severity disturbance is different than the opposite change in disturbance severity (Figure $3 A$ and $B$ ).

The usefulness of the model in real-world forests depends on how often large jumps in disturbance severity occur and whether these cause the system to spend most of its time away from the response surface, with time lags so large that another change in control variables occurs before the system approaches the equilibrial attractor surface. In the words of Poston and Stewart (1978, p. 401), "the slow seeker after equilibrium will generally be chasing it from so far off that the catastrophe theory geometry is not useful for describing what happens." We assess the usefulness of catastrophetheory by attempting to apply it directly to case studies.

\section{The Conceptual Model and Dynamics of Three Systems}

Detailed case studies of dynamics for study areas in Upper Michigan, northern Minnesota, and the northern Amazon are examined here and qualitatively related to the conceptual model.

U pper Michigan. Hemlock-hardwood forests occur on deep loam to sandy loam soils and are dominated by eastern hemlock (Tsuga canadensis) and sugar maple (Acer saccharum), associated with red maple (A cer rubrum), basswood (Tilia americana), and yellow birch (Betula alleghaniensis). Many studies of stability of these forests after disturbance have been reported in the literature. In summary, they show that high-severity disturbances, including natural fire in blowdown slash and clear-cutting followed by slash burning or scarification of the soil, lead to conversion of northern hardwoods-hemlock to aspen (Populus tremuloides) and paper birch (Betula papyrifera) (Stoeckeler 1948; Graham and others 1963; Fralish 1972; Frelich and Lorimer 1991); that moderate-severity disturbances including surface fire, heavy canopy windthrow, and canopy clear-cut with minimal understory disturbance can maintain the predisturbance composition-either hemlockhardwood or aspen-paper birch (Zon and Scholz 1929; Shirley 1931, 1932; Zehngraff 1949; Erye and Zillgitt 1953; Hubbard 1972; Frelich and Lorimer 1991) - and that low-severity to moderate-severity disturbances including selection cutting, spot fire, and blowdown allow forests to remain as hemlockhardwood or cause disturbance-mediated accelerated succession from aspen-birch to northern hardwood-hemlock (Eyre and Zillgitt 1953; Heinselman 1954; Tubbs 1977; Frelich and Lorimer 1991; Abrams and Nowacki 1992; Frelich and Graumlich 1994). Hix and Barnes (1984) report a major fluctuation in the hemlock to sugar maple ratio after clear-cut logging, but their study area is still dominated by these species. As a whole, these studies verify the dynamics shown in Figure 4A for states 1 and 2, including switches between hemlock-hardwood and aspen forest types. They also verify the existence of the cusp (Figure 4A), because two alternative forest types are maintained by the same combination of control variables: moderate-severity disturbances and positive neighborhood effects.

Historical reconstruction of dynamicsin hemlockhardwood forest remnants shows a combination of strong positive overstory-understory neighborhood effects and a low-severity to moderate-severity disturbance regime (Figure 4A). Analyses of neighborhoods on mapped plots in old-growth stands shows that the overstory-understory type of neighborhood effects are strongly positive. There is nearly always a layer of suppressed seedlings and saplings present, the composition of which reflects the proportional abundance of each species in the canopy at the neighborhood ( 0.01-0.1 ha) and stand ( 1-10 ha) spatial scales. These positive neighborhood effects can be so strong that hemlock and sugar maple are able to form and maintain separate patches, so that the landscape is a hardwoodconifer mosaic, with patches stable in composition for many tree generations (Frelich and others 1993; Frelich and Reich 1995a).

The natural disturbance regime features rare severe disturbances such as intense fires (rotation periods of a few thousand years), infrequent moderately severe disturbances such as surface fires and stand-leveling blowdown (rotation periods of 1000- 

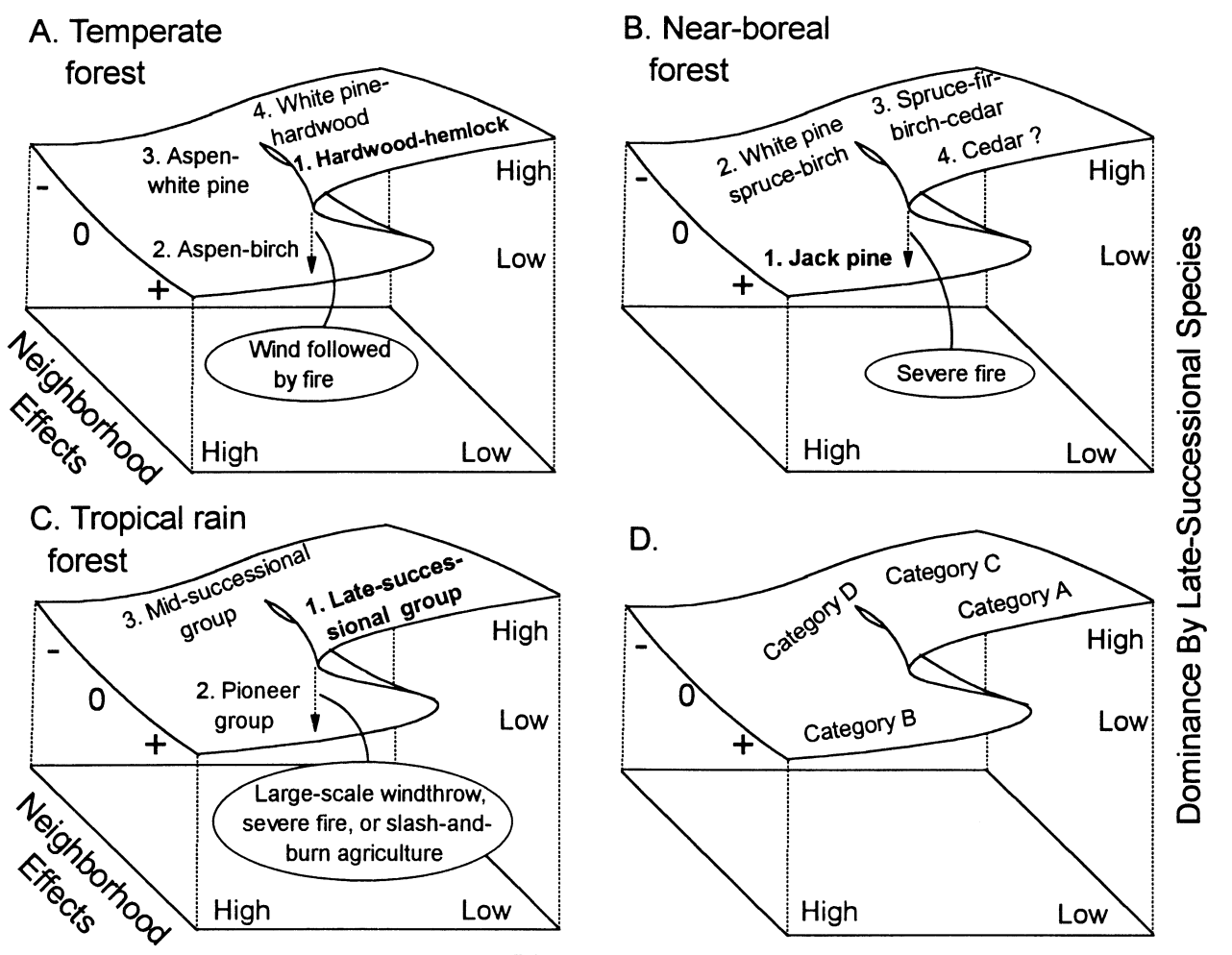

Disturbance Severity

Figure 4. Proposed response surfaces (or equilibrial attractors) and categories of dynamics for forest stands. For each case study $(A-C)$, the most common vegetation state under the natural disturbance regime is number ed in boldface. Disturbance types that can cause stands with positive neighborhood effects to go over thecusp are shown in the oval for each case. Details are in the text for each case study. Response surfaces for A northern hardwood-hemlock, birch-aspen, and white pine dynamic system in Upper Michigan; B jack pine, white pine, and spruce-fir-birch-cedar dynamic system in the BWCAW; and C tierra firme, slash-and-burn, or windfall-and-fire dynamic system in Venezuelan Amazon rain forest. D A schematic view of categories of forest dynamics when cross-classified by disturbance-regime severity and neighborhood effects. Details about each category are provided in Table 1 and the text.

2000 years), moderately frequent low-severity wind disturbance removing $10 \%-30 \%$ of the canopy trees (rotation periods of $50-300$ years), and frequent single-tree death due to senescence and windthrow (Canham and Loucks 1984; Whitney 1986; Frelich and Lorimer 1991). Thus, under the natural disturbance regime, most of this landscape was at state 1 and very rarely made excursions to state 2 (Figure 4A). This is a stark contrast to the current landscape, because widespread logging followed by burning of slash between 1880 and 1920 effectively made a formerly rare disturbance typecanopy removal and subsequent severe firecommon, converting the dominant forest on the landscape to state 2 (Lorimer 1977; Frelich and Lorimer 1991; Frelich 1995).

Other dynamics than switches between aspenbirch and hemlock-hardwood also occur in these forests. Sometimes species such as white pine (Pinus strobus) invade aspen-birch instead of succession directly back to hemlock-hardwood. White pine has neutral overstory-understory neighborhood effects (Frelich and Reich 1995a) and, if the species comes to dominate, stands move to state 3 or 4 in Figure 4A. Under a low-severity disturbance regime, sugar maple and hemlock replace white pine by taking over each neighborhood as older pines die, causing a trend toward state 1 (Whitney 1987; Abrams and Scott 1989). If high-severity fires occur, then many white pines will be killed and immediately replaced by aspen, causing a trend toward state 2 . Repeated episodes of moderate-intensity fire at intervals long enough to allow younger pines to become fire resistant could perpetuate white pine (Tester and others 1997). However, the disturbance regime in these forests is not stable; there is variability in intervals of time between fires and severity of sequential fires at a given point on the landscape (Johnson 1992; Whelan 1995). Thus, white pine stands are pushed up and down the slope (Figure $4 \mathrm{~A}$ ), with continuousmajor or minor fluctuations in composition. 
Northern Minnesota's Boundary Waters Canoe Area Wilderness (BWCAW). Near-boreal jack pine (Pinus banksiana)/aspen forests on thin soils over granite were perpetuated by canopy-killing fires at a mean recurrence interval of about 50 years (Heinselman 1973; Van Wagner 1978). Restocking after fire is by serotinous seed of jack pine (Rudolf 1965), and by root sprouting or long-distance seed transport for aspen. There are strong positive disturbance-activated neighborhood effects, and the tree-species composition within stands is similar before and after fire (Heinselman 1981; Ohmann and Grigal 1981). Thus, the fires often do not cause compositional succession, so vegetation remains in state 1 (Figure 4B).

Since 1910, fire frequency has been greatly reduced (Heinselman 1981), and many stands are now proceeding along formerly uncommon successional pathways (Grigal and Ohmann 1975; Frelich and Reich 1995b). Analyses of neighborhoods (all trees within a 9-m radius) on two old-growth mapped plots indicate that overstory-understory neighborhood effects are negative for the original postfire jack pine cohort and neutral for the other species that colonized the stands during the last century (Frelich and Reich 1995b). Because they are unable to favor their own reproduction in the absence of severe fire, and unable to disfavor that of other species, jack pine and aspen are being replaced. Such stands are proceeding to a position below the equilibrial surface beneath state 3 (Figure 4B), a late-successional mosaic of monodominant neighborhoods from 35 to $1000 \mathrm{~m}^{2}$ in size composed of paper birch, northern white cedar (Thuja occidentalis), black spruce (Picea mariana), or balsam fir (A bies balsamea). Low-severity disturbancesgradually remove the jack pine canopy and allow a stand to approach the surface by the time the latesuccessional species come to dominate the stand [state 3 of Figure 4B (Frelich and Reich 1995b)]. Neighborhoods dominated by any of the four species may succeed to each of the other three species so that, in the absence of fire, a shifting-patch mosaic with neutral neighborhood effects results. At the stand scale, the mosaic is a fairly homogeneous mixture of the four patch types at scales from 1 to 16 ha (Frelich and Reich 1995b).

There is some evidence, in the form of successional and transition probability analyses, that white cedar may have the potential to develop positive neighborhood effects, if it reaches a threshold patch size/abundance in very old BWCAW forests (Grigal and Ohmann 1975; Frelich and Reich 1995b). This could lead to the hypothetical state 4 in Figure 4B, where white cedar could take on a role similar to hemlock in Upper Michigan, meaning that it would regenerate after windthrow and surface fires and would not convert back to jack pine/ aspen unless an intense fire occurred. As with the northern hardwood-aspen system, jack pine and white cedar can both be perpetuated by moderate-severity surface fires (Ahlgren 1970; Heinselman 1973), so the cusp (Figure 4B) is likely to exist. State 2 in Figure 4B, a mixture of white pine, spruce, and birch, occurs on sites such as lakeshores and islands where fire severity tends to be moderate. These forests have neutral to negative neighborhood effects and, like jack pine forests, also succeed to state 3 or 4 if disturbance-regime severity shifts to low levels (Heinselman 1973; Frelich and Reich 1995a).

Tropical rain forest, northern A mazon Basin, Venezuela. Several species-rich but distinct forest typesassociated with distinct topo-edaphic positionsform a landscape mosaic in the region of the Rio Negro river near San Carlos, Venezuela. Patterns and mechanisms of community dynamics under natural and human disturbance regimes have been studied for the upland tierra firme forests on relatively nutrient-poor Oxisol soils (Uhl 1987; Uhl and others 1988; Reich and others 1995; Ellsworth and Reich 1996). In several ways, these tierra firme forests mimic the hemlock-hardwood forests of the temperate zone, although larger species complexes substitute for both the hemlock-hardwood and aspen communities. At this point, the data on tierra firme forests are consistent with dynamics we see in the temperate hardwood-hemlock forests, although there is insufficient evidence to prove the case. The primary tierra firme forest has a combination of positive overstory-understory neighborhood effects and a low-severity disturbance regime (state 1, Figure 4C). The natural disturbance regime is dominated by wind (Uhl and others 1988). In both small (single treefall) and large ( 0.4 ha, multiple treefall) gaps, trees that become dominant come from an advanced regeneration pool made up of the same late-successional, shade-tolerant species that form the mature forest canopy (Uhl and others 1988). Pioneer species represent a very small fraction (by species number or density) of the total assemblage.

Similar to hemlock-hardwood forests, to change vegetation state requires a disturbance of sufficient severity to overwhelm the neighborhood effects. Three such disturbances warrant mention. Two natural disturbances can occur, but both are rare. Wildfires can occur in tierra firme forest, and their frequency may well be related to shifts in precipitation (Sanford and others 1985). When such fires are intense enough to kill most of the canopy dominants and the advanced regeneration, it is likely that 
subsequent recolonization will be by the pioneer/ early successional complex of species that successfully invade after human-induced fires (Uhl 1987); thus, the vegetation state falls over the cusp (state 2, Figure 4C). Similarly, large areas (the aforementioned $\gg 0.4$-ha gaps) of blowdown occur on rare occasions and allow the pioneer complex of species to be relatively successful (Uhl and others 1988), resulting in a shift in vegetation state. Human disturbance, whether due to logging and fire, or the same followed by a short period of agriculture, mimics the effects of both fire and a large multiple treefall. Plots, usually 1-2 ha, are cleared, burned, and then used for agriculture. Once abandoned, pioneer and early secondary successional species dominate (Uhl 1987), indicating a compositional catastrophe from the predisturbance vegetation state. The vegetation then makes a predictable, incremental change toward state 1 (Figure 4C), as species with a continuum of life history and ecophysiological traits (similar to those of temperate zone species) replace one another (Uhl 1987; Reich and others 1992, 1995; Ellsworth and Reich 1996) as light and nutrient availability decline in the understory, and the short-lived individuals of the pioneer species die, opening up canopy spaces. This change may be direct, if shade-tolerant species with strong neighborhood effects invade right away (as shown in Figure $3 A$ ), or via a series of steps through state 3 (midsuccessional group in Figure 4C), if the stand is invaded by species with neutral or negative neighborhood effects.

\section{Can the Cusp-Catastrophe Model Be Applied Quantitatively?}

Our ability to parameterize the model quantitatively at this time is poor at best. The definition of disturbance severity that uses the proportion of mature trees and advanced reproduction killed in a disturbance seems conceptually straightforward. However, we have not resolved how to combine advanced regeneration and mature trees, as well as rootstocks capable of resprouting, into a single quantitative number that expresses the effects of a disturbance episode. For the time being, we can use ordered categories of disturbance severity (low, moderate, and high).

The response to disturbance of interest here is composition of the new forest canopy that develops a few decades after disturbance, after transient dynamics have played themselves out, and it becomes obvious which species will dominate the postdisturbance forest. One can obtain data on response by following the progress of a stand after disturbance on long-term study plots, or use stand- history reconstructions to learn how stands responded to previous disturbances. To parameterize the model, the type of long-term stand data just discussed would be needed for stands starting out with early- and late-successional species, each subjected to high-, moderate, and low-severity disturbances. More than three levels of disturbance severity would have to be observed to fix the location of the edge of the cusp accurately along the disturbance-severity gradient.

Needless to say, there are few examples of forests where we know all these things. In our judgment, we cannot at this time parameterize the model and predict the change in dominance by late-successional species ( $z$ axis) that would result from a disturbance of severity $x$, if the forest had neighborhood effects of strength $y$. However, for the case of the northern hardwood-hemlock-aspen-white pine successional system (see the preceding U pper M ichigan section and Figure 4A for background information), there are enough detailed case studies published that we can show, semiquantitatively, using the three categories of disturbance severity discussed earlier, that the pattern of response to disturbance does match the hypothesized cusp-catastrophe model.

A survey of the literature was undertaken to find case studies from the Upper Midwest that document the nature of the relationship between northern hardwood-hemlock forests and aspen-paper birch forests. When the case studies are summarized in graphical form, the structure of the cusp is clearly visible (Figure 5). All of the 18 stands that received high-severity disturbances-those that caused major mortality in both the overstory and understorywere heavily dominated by aspen-paper birch after disturbance, regardless of whether they were aspenpaper birch ( 7 cases) or hardwood-hemlock (11 cases) prior to disturbance. Case studies of response to moderate-severity disturbances-those that caused major mortality in either the overstory or understory-showed that all stands remained very similar in composition after the disturbance as before, again regardless of the prior condition. Of particular interest is that hardwood-hemlock stands and aspen-paper birch stands stayed similar in composition after two different types of disturbance: canopy clear-cutting/heavy windthrow (hardwoodhemlock, 12 cases; and aspen-paper birch, 7 cases) and surface fire (hardwood-hemlock, 10 cases; and aspen-paper birch, 3 cases). Low-severity disturbances that removed small pieces of either the overstory or the understory allowed hardwoodhemlock forest to stay in that condition (30 cases). Forest survey information also shows progressive 


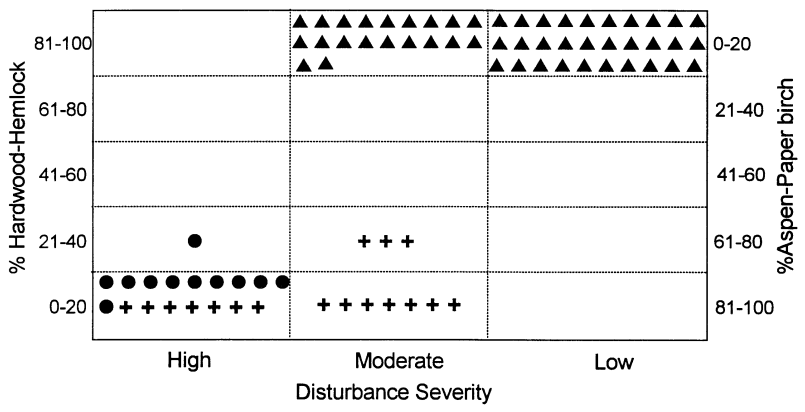

Figure 5. Case studies of hardwood-hemlock and aspenpaper birch forest response to disturbance. The left and right y axes are complimentary to each other and show forest canopy composition (percent basal area or density of stems) in ordered categories after disturbance (3-30 years after disturbance for stands dominated by aspenpaper birch, and 20-50 years after disturbance for stands dominated by hardwood-hemlock). Stands that were hardwood-hemlock dominated both before and after disturbance ( $\mathbf{\Lambda})$ are from case studies by Zon and Scholz (1929), Eyre and Zillgitt (1950, 1953), Tubbs (1977), Hix and Barnes (1984), Frelich and Lorimer (1991), and Frelich and Graumlich (1994). Stands that were dominated by hardwood-hemlock prior to disturbance, but aspen-paper birch after disturbance $(\bullet)$, are from case studies by Stoeckeler (1948), Graham and others (1963), and Frelich and Lorimer (1991). Stands that were dominated by aspen-paper birch both before and after disturbance (+), are from case studies by Shirley (1931, 1932), Zehngraff (1949), Stoeckeler and M acon (1956), Hubbard (1972), Fralish (1972), Heinselman (1973), and Frelich and Reich (1995b).

conversion of aspen-paper birch forest to hardwoodhemlock forest on 850,000 ha throughout Wisconsin, Minnesota, and Michigan, in stands receiving only low-severity disturbance over a 40-year period (Heinselman 1954) (not shown in Figure 5; however, this conversion is represented by upward arrows in Figure 3).

The region of the response surface with neutralnegative neighborhood effects-white pine forests for the case of interest here-is expected to show a continuous response to disturbance severity (Figure 4A, states 3 and 4). Thus, we expect a stepped response among the three categories of disturbance. The endpoints of the disturbance-severity gradient are the same as in Figure 5 (that is, dominance by aspen-paper birch after severe disturbance, and dominance by hardwood-hemlock after an extended period with only low-severity disturbance), but we expect that forest response to moderateseverity disturbance will result in a cluster of points in the middle of the range of dominance by shadetolerant species, rather than the two alternate states shown in Figure 5. Several such case studies are documented in the literature, in forests with various mixtures of white pine, aspen, paper birch, and hardwoods, that fall in the middle of the low-high gradient of dominance by late-successional species, after a variety of moderate-severity disturbances (Frissell 1973; Heinselman 1973, 1981; Frelich and Lorimer 1991; Frelich and Reich 1995a). Research in progress will measure disturbance severity more precisely. These studies will enable quantitative analysis of effects of incremental changes in disturbance severity through the moderate range, which will in turn provide better illustration of the differences in shape of the response surface between forests dominated by species with positive, and neutral or negative, neighborhood effects and possibly lead to parameterization of the model.

\section{Discussion}

\section{Categories of Forest Dynamics}

A simple cross-classification of neighborhood effects (negative/neutral versus positive) and disturbanceregime severity (low versus high) suggests four categories of forest dynamics (Figure 4D). The data from the case studies and logical consequences of the different combinations of neighborhood effects and disturbance severities lead to some interesting contrasts hypothesized among the four categories (Table 1). In those forests with strong positive neighborhood effects, the common types of natural disturbances may kill individual trees or remove the canopy from stands without initiating succession, thus keeping composition stable but causing large patches to form that are in a young stage of stand development. Patches of differing species composition may be formed by processes other than disturbance (Heinselman 1973; Frelich and others 1993; Pacala and others 1996). These forests with positive neighborhood effects also tend to have stable species composition across several spatial scales. The major contrast between the dynamics of forests with positive overstory-understory effects (category A) and those with positive disturbance-activated effects (category B) is in the role of severe disturbance. In category A forests, severe disturbance causes a compositional catastrophe and initiates an episode of succession, whereas, in category B forests, severe disturbance perpetuates the current species composition and merely creates patches of different ages. Thus, forested landscapes in category A will have a few stands dominated by earlysuccessional species embedded in a stable matrix of shade-tolerant species (Bormann and Likens 1979), whereas category B forested landscapes will have a matrix of young early-successional stands with a 
Table 1. Spatial and Temporal Characteristics of Forests in Four Dynamic Categories

\begin{tabular}{|c|c|c|c|c|}
\hline \multirow[b]{2}{*}{ Characteristic } & \multicolumn{4}{|l|}{ Dynamic Category } \\
\hline & $A$ & B & C & $\mathrm{D}$ \\
\hline $\begin{array}{l}\text { Dominant cause of } \\
\text { patch formation } \\
\text { (on fairly uniform } \\
\text { physiographical site) }\end{array}$ & $\begin{array}{l}\text { Interactions among } \\
\text { species }\end{array}$ & $\begin{array}{l}\text { Interactions among } \\
\text { species, variation in } \\
\text { fire intensity }\end{array}$ & Treefall gaps & $\begin{array}{l}\text { Disturbance of any } \\
\text { severity or size }\end{array}$ \\
\hline Patch size & Small (1-100 ha) & Variable & Very Small ( <1 ha) & $\begin{array}{l}\text { Variable but many } \\
\text { patches will be large }\end{array}$ \\
\hline $\begin{array}{l}\text { Overstory-understory } \\
\text { neighborhood effects } \\
\text { (between episodes } \\
\text { or in the absence of } \\
\text { severe disturbance) }\end{array}$ & Positive & Negative & Neutral or negative & Neutral or negative \\
\hline $\begin{array}{l}\text { Disturbance-activated } \\
\text { neighborhood effects } \\
\text { (at the time of } \\
\text { severe disturbance) }\end{array}$ & Negative & Positive & Neutral or negative & Neutral or negative \\
\hline $\begin{array}{l}\text { Role of high severity } \\
\text { disturbance }\end{array}$ & $\begin{array}{l}\text { Destabilizing at all } \\
\text { spatial scales, } \\
\text { replaces existing } \\
\text { species and initiates } \\
\text { episode of succession }\end{array}$ & $\begin{array}{l}\text { Stabilizing at all spatial } \\
\text { scales if occurs at } \\
\text { intervals less than } \\
\text { tree life span; } \\
\text { perpetuates current } \\
\text { species and kills } \\
\text { invading species; } \\
\text { creates patches of } \\
\text { different ages }\end{array}$ & $\begin{array}{l}\text { Destabilizing, replaces } \\
\text { existing species, } \\
\text { initiates episode of } \\
\text { succession }\end{array}$ & Perpetuates instability \\
\hline $\begin{array}{l}\text { Role of low-moderate } \\
\text { severity disturbance }\end{array}$ & $\begin{array}{l}\text { Perpetuates existing } \\
\text { condition; creates } \\
\text { patches of different } \\
\text { ages }\end{array}$ & Minor & $\begin{array}{l}\text { Perpetuates existing } \\
\text { condition; creates } \\
\text { patches of different } \\
\text { ages }\end{array}$ & Perpetuates instability \\
\hline $\begin{array}{l}\text { Dominant cause of } \\
\text { successional episode } \\
\text { at stand scale }\end{array}$ & $\begin{array}{l}\text { Severe disturbance hits } \\
\text { by chance, such as } \\
\text { windthrow-fire } \\
\text { sequence }\end{array}$ & Chance lack of fire & $\begin{array}{l}\text { Severe disturbance, } \\
\text { such as crown fire }\end{array}$ & $\begin{array}{l}\text { Disturbance of any size } \\
\text { or severity }\end{array}$ \\
\hline $\begin{array}{l}\text { Dominant cause of } \\
\text { successional episode } \\
\text { at landscape level }\end{array}$ & $\begin{array}{l}\text { Change in disturbance } \\
\text { regime/climate }\end{array}$ & $\begin{array}{l}\text { Change in disturbance } \\
\text { regime/climate }\end{array}$ & $\begin{array}{l}\text { Severe disturbance or } \\
\text { changing } \\
\text { disturbance regime }\end{array}$ & $\begin{array}{l}\text { Large-scale } \\
\text { disturbance }\end{array}$ \\
\hline $\begin{array}{l}\text { Stability of } \\
\text { neighborhood } \\
(\sim 0.01-0.1 \mathrm{ha})\end{array}$ & $\begin{array}{l}\text { High (several tree } \\
\text { lifetimes) }\end{array}$ & High & $\begin{array}{l}\text { Low (1-2 tree } \\
\text { lifetimes) }\end{array}$ & Low \\
\hline $\begin{array}{l}\text { Stability of stand } \\
\quad(\sim 1-10 \text { ha })\end{array}$ & High & High & Low-moderate & Low \\
\hline $\begin{array}{l}\text { Stability of landscape } \\
\text { ( 10-1000 ha) }\end{array}$ & High & High & Moderate-high & Variable \\
\hline $\begin{array}{l}\text { Landscape } \\
\text { characteristics }\end{array}$ & $\begin{array}{l}\text { A few patches of early } \\
\text { successional forest } \\
\text { (category B or D) in } \\
\text { a matrix of late- } \\
\text { successional species } \\
\text { stable-patch mosaic }\end{array}$ & $\begin{array}{l}\text { A few patches of } \\
\text { late-successional } \\
\text { forest (category C) in } \\
\text { a matrix of early- } \\
\text { successional forest }\end{array}$ & $\begin{array}{l}\text { A few patches of early } \\
\text { successional forest } \\
\text { (category B or D) in } \\
\text { a matrix of shifting } \\
\text { patch mosaic }\end{array}$ & $\begin{array}{l}\text { Patches of early- and } \\
\text { late-successional } \\
\text { species }\end{array}$ \\
\hline
\end{tabular}
$(A-D)$. 
few embedded stands (or individual trees) of latesuccessional remnants that were by chance missed by disturbance (Heinselman 1973) (Table 1).

In category $C$ and $D$ forests with negative or neutral neighborhood effects, disturbances of any severity are likely to cause fluctuations in species composition (forests on the sloping part of response surface in Figure 4D). Patches of different ages and different species composition will often be geographically coincidental rather than independent, as they were in categories A and B. Such forests are likely to exhibit ongoing instability at some spatial scale. If disturbances are small and severity is low (for example, treefall gaps in temperate and tropical forests), then individual neighborhoods will change composition frequently (every 1-2 tree lifetimes), while stands have a shifting-patch mosaic of different species that could be stable. Shugart (1984) suggests that 50 times the mean patch size is a reasonable criterion for stability. The mean patch size on mapped plots in 191-year-old forest in the BWCAW was $35 \mathrm{~m}^{2}$ (Frelich and Reich 1995b), and 50 times that is approximately 0.2 ha, suggesting an approximate minimum stand size that could be stable with a shifting-patch mosaic. Forests in category D with large, moderately severe to severe disturbances would be unstable at the neighborhood and stand scales, but could be stable at the landscape scale if the landscape is more than 50 times the size of the disturbance patches (Table 1).

A survey of the literature indicates that some forests fit into or move among all four categories of dynamics. Category A dynamics, with strong positive overstory-understory neighborhood effects and low-severity disturbance regimes, occur in forests dominated by extremely shade-tolerant species that have fuel types or climates discouraging intense fire. This includes the hemlock-hardwood forests in our Upper Michigan study area and throughout eastern North America (Runkle 1982; Foster and Zebryk 1993; Peterson and Carson 1995), deciduous beech forests in J apan (Ohkubo and others 1988; Yamamoto 1989; Nakashizuka and lida 1995), and western hemlock (Tsuga heterophylla)/Sitka spruce (Picea sitchensis) forests in southeast Alaska (Deal and others 1991). The spatially explicit resource-based model SORTIE predicts that long-term stability at the neighborhood and stand scales should be expected in hemlock-beech (Fagus grandifolia) forests in Connecticut (Pacala and others 1996).

Category B dynamics with strong positive disturbance-activated neighborhood effects and a highseverity disturbance regime include cases across the North American boreal forest, with canopy-killing fires in Saskatchewan (Dix and Swan 1971), northern Minnesota (Heinselman 1973), and Quebec (Bergeron and Dubuc 1989). Lodgepole pine (Pinus contorta) in the United States and Canadian Rockies al so displays these dynamics (Romme 1982; J ohnson and Fryer 1989; Turner and others 1997).

Forests with negative or neutral neighborhood effects and low-severity disturbance regimes (category C dynamics) occur in the previously mentioned shifting-patch mosaic of paper birch, balsam fir, white cedar, and black spruce in the BWCAW study area in the absence of fire (Frelich and Reich 1995b). Pastor and colleagues (1987) propose that red spruce (Picea rubens) or white spruce (Picea glauca) can alternate with paper birch and aspen at the neighborhood scale due to feedbacks of litterfall of spruce on nutrient availability. The situation is similar in some tropical rain forests, although the number of species mixed together is very large. Hubbell and Foster (1986) show that, in a Panamanian tropical forest, individual trees are replaced by other species by chance, whereas the entire latesuccessional group of species is self-replacing at the stand level.

There are many forest types that experience moderate to moderately severe disturbance regimes and continuous fluctuation in species composition at all spatial scales (category D dynamics). These inherently unstable forests include most of those dominated by midsuccessional species, where severe disturbance allows the return of a different set of pioneer species, and lack of severe disturbance allows a still different set of more shade-tolerant species to invade. In other words, the timing of disturbances is frequently out of synch with the life-history characteristics of the species present in a region, so that neither a stable endpoint to succession nor a disturbance-caused climax can result. Such forests include white pine and mixed whitered pine (Pinus resinosa) forests in eastern North America (Hough and Forbes 1943; Foster 1988a, 1988b; Frelich and Reich 1995a), red maple in the northeastern United States (Lorimer 1984), red oak (Quercus rubra) in eastern North America (Lorimer 1983; Nowacki and others 1990; Abrams 1992), and Libocedrus bidwillii in New Zealand (Veblen and Stewart 1982). Forests that formerly had dynamics from categories A, B, or C may al so fall in category D if they have experienced a compositional catastrophe. Currently, this includes second-growth forests in temperate zones, such as second-growth beech, birch, sugar maple, and hemlock that suffered logging followed by burning during the late 1800s to early 1900s in eastern North America [for example, 
see Oliver and Stephens (1977) and Brisson and others (1994) ].

\section{Implications of the Conceptual Model}

The model can help guide thinking about ecological processes and help design long-term studies to answer certain questions. If one assumes that the case-study data reviewed above do qualitatively fit the model, then there are several implications for the spatial and temporal dynamics of forests.

Implication 1. Punctuated stability may occur in forest types with strong positive neighborhood effects in dynamic category A. Stability never lasts forever. The more stable a system is, the more severe a disturbance must be to overcome the stability and the less frequent such a disturbance will be. However, such a disturbance will eventually occur, changing the species composition and initiating an episode of succession.

Implication 2. Lack of compositional stability is likely in those forests occurring on the neutral or negative neighborhood effect region of the response surface. The lack of stability is a direct result of negative neighborhood effects, the fact that no two sequential disturbances are likely to be identical in severity, and that composition here is sensitive to minor differences in disturbance severity. If disturbance-regime severity functions as a control variable as proposed here, then category $D$ may be an inherently unstable dynamic category.

Implication 3. Neighborhood effects and spatial/ temporal stability of forests are strongly related. The autecology and interactions among adjacent trees link processes at the individual tree spatial scale with those at the stand and possibly landscape spatial scales. Positive feedback loops among individuals have been shown to lead to patchiness in forests and many other vegetation types around the world (Wilson and Agnew 1992). This can in turn influence disturbance severity and the response of the stand to disturbance.

Implication 4. The experience of many researchers and forest managers may be limited to one part of the response surface (Figure 1 ). The conceptual model shows how a given forested area may move among the dynamic categories (Figures 3 and 4, and Table 1). However, these changes play out over very long time periods in any one stand and over large geographical areas at any one point in time. Therefore, many individual researchersand forest managers have experience with only a small portion of the proposed response surface. The model may show how forests in a given study area fit into a larger picture, and how seemingly unrelated forests may belinked.

\section{Conclusions}

There will always be changes in climate, disturbance regime, and other factors that cause movement among the four dynamic categories. Although we have evidence that jack pine forests in the BWCAW were in category $B$ for several centuries, the birchfir-cedar-spruce stands in our BWCAW study area have moved from category $B$ to category $C$ in only the last few decades. In fact, the landscape comprises a mixture of stands that are still jack pine undergoing dynamics of category $B$, and those that have moved on to category $C$ as a result of lowered fire frequency since 1900 . Thus, the conceptual model does provide a framework for thinking about the types of qual itative changes one expects in forest characteristics under a changing disturbance regime. The case studies show that many forests remain on one part of the surface, close to the equilibrial attractor, for long periods. A change in category of dynamics accompanies successional changes in forest tree composition. A given stand may stay in one corner of the response surface (Figure 1) for extended periods, oscillate between two categories of dynamics, or roam across the response surface due to changes in disturbance regime.

One caveat to remember about this entire report is that we are examining the theoretical interaction of only two variables-disturbance-regime severity and neighborhood effects-on forest dynamics. In effect, the conceptual model and the categories in Table 1 represent a complex thought experiment, backed up by limited empirical case studies. The patch patterns of forests in many, if not most, cases will be more complicated than presented here. Often, landscapes will have lakes, ravines, ridges, rock outcrops, and bodies of very different soil types interspersed throughout, or regions in time or space where keystone animals vary in abundance. These physiographical and biotic features can allow persistence of patches by altering the local effects of disturbance and competitive balance among species. The actual patch dynamics of forests at neighborhood, stand, and landscape levels should be a blend between dynamics caused by nonhomogeneous landscapes, neighborhood effects, disturbance, and other factors. However, it is still valuable to think about how individual factors and paired factors influence the system in isolation before attempting synthesis of all variables. The logical continuation of the line of reasoning in this report is twofold: (a) to obtain more detailed case studies of disturbance and neighborhood effect interactions to determine whether the conceptual model can be further veri- 
fied, especially in other regions; and (b) to synthesize the effects of disturbance and neighborhood effects together with water and nutrient resource gradients, biotic influences, and physiographical influences on the vegetation, with the ultimate goal of a more complete understanding of vegetation dynamics.

\section{ACKNOWLEDGEMENTS}

Research on the Great Lakes Area study sites was supported by the Wilderness Research Foundation (Ely, Minnesota) and by National Science Foundation Grant DEB 9423065. Research in the Amazon study site was supported by National Science Foundation Grant BSR 9196217.

\section{REFERENCES}

Abrams MD. 1992. Fire and the development of oak forests. BioScience 42:346-53.

Abrams MD, Nowacki GJ . 1992. Historical variation in fire, oak recruitment, and post-logging accelerated succession in central Pennsylvania. Bull Torrey Bot Club 119:19-28.

Abrams MD, Scott ML. 1989. Disturbance-mediated accelerated succession in two Michigan forest types. For Sci 35:42-9.

Ahlgren CE. 1970. Some effects of prescribed burning on jack pine reproduction in northeastern Minnesota. St. Paul University of Minnesota Agricultural Experiment Station; Miscellaneous Report 94, Forestry Series 5-1970.

Bergeron Y, Dubuc M. 1989. Succession in the southern part of the Canadian boreal forest. Vegetatio 79:51-63.

Bormann FH, Likens GE. 1979. Pattern and process in a forested ecosystem. New York: Springer-Verlag.

Brisson J, Bergeron Y, Bouchard A, Leduc A. 1994. Beech-maple dynamics in an old-growth forest in southern Quebec. Ecoscience 1:40-6.

Canham CD, Loucks OL. 1984. Catastrophic windthrow in the presettlement forests of Wisconsin. Ecology 65:803-9.

Clements FE. 1936. Nature and structure of the climax. J Ecol 24:252-84.

Davis MB. 1981. Quaternary history and the stability of forest communities. In: West DC, Shugart HH, Botkin DB, editors. Forest succession, concepts and application. New York: Springer-Verlag. p 132-53.

Davis MB. 1986. Climatic instability, time lags, and community disequilibrium. In: Diamond J, Case TJ, editors. Community ecology. New York: Harper and Row. p 269-84.

Deal RL, Oliver CD, Bormann BT. 1991. Reconstruction of mixed hemlock-spruce stands in coastal southeast Alaska. Can J For Res 21:643-54.

Delcourt PA, Delcourt HR. 1987. Long-term forest dynamics of the temperate zone. New York: Springer-Verlag.

Dix RL, Swan J MA. 1971. The roles of disturbance and succession in upland forest at Candle Lake, Saskatchewan. Can J Bot 49:657-76.

Ellsworth DS, Reich PB. 1996. Photosynthesis and leaf nitrogen in five Amazonian tree species during early secondary succession. Ecology 77:581-94.
Eyre FH, Zillgitt WM. 1950. Size-class distribution in old-growth northern hardwoods twenty years after cutting. Washington (DC): US Department of Agriculture, Forest Service; Lake States Forest Experiment Station, Station Paper 21.

Eyre FH, Zillgitt WM. 1953. Partial cuttings in northern hardwoods of the Lake States. Washington (DC): US Department of Agriculture, Forest Service; Lake State Forest Experiment Station, Technical Bulletin 1076.

Foster DR. 1988a. Disturbance history, community organization and vegetation dynamics of the old-growth Pisgah forest, south-western New Hampshire, USA.J Ecol 76:105-34.

Foster DR. 1988b. Species and stand response to catastrophic wind in central New England, USA.J Ecol 76:135-51.

Foster DR, King GA. 1986. Vegetation pattern and diversity in S.E. Labrador, Canada: Betula Papyrifera (birch) forest development in relation to fire history and physiography. J Ecol 74:465-83.

Foster DR, Zebryk TM. 1993. Long-term vegetation dynamics and disturbance history of a Tsuga-dominated forest in New England. Ecology 74:982-98.

Fralish JS. 1972. Youth, maturity and old age. In: Aspen, symposium proceedings. Washington (DC): US Department of Agriculture Forest Service; General Technical Report NC-1. p 52-8.

Frelich LE. 1995. Old forest in the Lake States today and before European settlement. Nat Areas] 15:157-67.

Frelich LE, Calcote RR, Davis MB, Pastor J. 1993. Patch formation and maintenance in an old-growth hemlock-hardwood forest. Ecology 74:513-27.

Frelich LE, Graumlich LJ . 1994. Age-class distribution and spatial patterns in an old-growth hemlock-hardwood forest. Can J For Res 24:1939-47.

Frelich LE, Lorimer CG. 1991. Natural disturbance regimes in hemlock-hardwood forests of the upper Great Lakes region. Ecol Monogr 61:145-64.

Frelich LE, Reich PB. 1995a. Neighborhood effects, disturbance, and succession in forests of the western Great Lakes Region. Ecoscience 2:148-58.

Frelich LE, Reich PB. 1995b. Spatial patterns and succession in a Minnesota southern-boreal forest. Ecol Monogr 65:325-46.

Frelich LE, Sugita S, Reich PB, Davis MB, Friedman SK. 1998. Neighbourhood effects in forests: implications for within-stand patch structure. J Ecol 86:149-61.

Frissell SS. 1973. The importance of fire as a natural ecological factor in Itasca State Park, Minnesota. Quat Res 3:397-407.

Gatto M, Rinaldi S. 1987. Some models of catastrophic behavior in exploited forests. Vegetatio 69:213-22.

Graham SA, Harrison RP J r, Westell CE J r. 1963. Aspens: phoenix trees of the Great Lakes Region. Ann Arbor: University of Michigan Press.

Grigal DF, Ohmann LF. 1975. Classification, description, and dynamics of upland plant communities within a Minnesota wilderness area. Ecol Monogr 45:389-407.

Heinselman ML. 1954. The extent of natural conversion to other species in the Lake States aspen-birch type. J For 52:737-8.

Heinselman ML. 1973. Fire in the virgin forests of the Boundary Waters Canoe Area, Minnesota. Quat Res 3:329-82.

Heinselman ML. 1981. Fire and succession in the conifer forests of northern North America. In: West DC, Shugart HH, Botkin DB, editors. Forest succession: concepts and applications. New York: Springer-Verlag. p 374-405. 
Hix DM, Barnes BV. 1984. Effects of clear-cutting on the vegetation and soil of an eastern hemlock-dominated ecosystem, western Upper Michigan. Can J For Res 14:914-23.

Holling CS. 1981. Forest insects, forest fires, and resilience. Washington, D.C.: USDA Forest Service; Fire regimes and ecosystem properties, General Technical Report WO-26. p 445-64.

Hough AF, Forbes RD. 1943. The ecology and silvics of forests in the high plateaus of Pennsylvania. Ecol Monogr 13:299-320.

Hubbard JW. 1972. Effects of thinning on growth and yield. In: Aspen, symposium proceedings. Washington (DC): US Department of Agriculture Forest Service; General Technical Report NC-1. p 126-30.

Hubbell SP, Foster RB. 1986. Biology, chance, and history and the structure of tropical rain forest tree communities. In: Diamond J , Case TJ, editors. Community ecology. New York: Harper and Row, p 314-29.

J acobson GL, Webb III T, Grimm EC. 1987. Patterns and rates of vegetation change during the deglaciation of eastern North America. In: Ruddiman WT, Wright HE, editors. The geology of North America, volume 3. Boulder (CO): Geological Society of America. p 277-88.

J ohnson EA. 1992. Fire and vegetation dynamics: studies from the North American boreal forest. Cambridge: Cambridge University Press.

J ohnson EA, Fryer GI. 1989. Population dynamics in lodgepole pine-Engelmann spruce forests. Ecology 70:1335-45.

J ones DD. 1977. The application of catastrophe theory to ecological systems. In: Innis GS, editor. New directions in the analysis of ecological systems, part 2. LaJ olla (CA): Sinulation Councils. p 133-48.

Loehle C. 1989. Catastrophe theory in ecology: a critical review and an example of the butterfly catastrophe. Ecol Modell 49:125-52.

Lorimer CG. 1977. The presettlement forest and natural disturbance cycle of northeastern Maine. Ecology 58:139-48.

Lorimer CG. 1983. Eighty-year development of northern red oak after partial cutting in a mixed-species Wisconsin forest. For Sci 29:371-83.

Lorimer CG. 1984. Development of red maple understory in northeastern oak forests. For Sci 30:3-22.

Ludwig D, Walker B, Holling CS. 1997. Sustainability, stability, and resilience. Conserv Ecol [online] http://www.consecol.org/ vol1/iss1/art7 1:7.

Nakashizuka T, lida S. 1995. Composition, dynamics and disturbance regime of temperate deciduous forests of M onsoon Asia. Vegetatio 121:23-30.

Nowacki GJ, Abrams MD, Lorimer CG. 1990. Composition, structure, and historical development of northern red oak stands along an edaphic gradient in north-central Wisconsin. For Sci 36:276-92.

Ohkubo T, Kaji M, Hamaya T. 1988. Structure of primary J apanese beech (Fagus japonica Maxim.) forests in the Chichibu Mountains, central J apan, with special reference to regeneration processes. Ecol Res 3:101-16.

Ohmann LF, Grigal DF. 1981. Contrasting vegetation responses following two forest fires in northeastern Minnesota. Am Midl Nat 106:54-64.

Oliver CD, Larson BC. 1990. Forest stand dynamics. New York: McGraw-Hill. (Biological Resource Management Series.)

Oliver CD, Stephens EP. 1977. Reconstruction of a mixed-species forest in central New England. Ecology 58:562-72.
Pacala SW, Canham CD, Saponara J, Silander JA J r, Kobe RK, RibbensE. 1996. Forest models defined by field measurements: estimation, error analysis and dynamics. Ecol Monogr 66:1-43.

Pastor J, Gardner RH, Dale VH, Post WM. 1987. Successional changes in nitrogen availability as a potential factor contributing to spruce declines in boreal North America. Can J For Res 17:1394-400.

Peterson CJ , Carson WP. 1995. Generalizing forest regeneration models: the dependence of propagule availability on disturbance history and stand size. Can J For Res 26:45-52.

Poston T, Stewart I. 1978. Catastrophe theory and its applications. London: Pitman.

Reich PB, Ellsworth DS, Uhl C. 1995. Leaf carbon and nutrient assimilation and conservation in species of differing successional status in an oligtrophic Amazonian forest. Funct Ecol 9:65-76.

Reich PB, Walters MB, Ellsworth DS. 1992. Leaf life-span in relation to leaf, plant, and stand characteristics among diverse ecosystems. Ecol Monogr 62:365-92.

Romme WH. 1982. Fire and landscape diversity in subalpine forests of Yellowstone National Park. Ecol Monogr 52:199221.

Rudolf PO. 1965. Jack pine (Pinus banksiana Lamb.). In: Fowells $\mathrm{HA}$, compiler. Silvics of forest trees of the United States. Washington (DC): US Department of Agriculture. p 338-54. (Agriculture Handbook: 271.)

Runkle JR. 1982. Patterns of disturbance in some old-growth mesic forests of eastern North America. Ecology 63:1533-46.

Sanford RL J r, Saldarriaga J , Clark KE, Uhl C, Herrera R. 1985. Amazon rainforest fires. Science 227:53-5.

Schoonmaker PK, Foster DR. 1991. Some implications of paleoecology for contemporary ecology. Bot Rev 57:204-45.

Shirley HL. 1931. Does light burning stimulate aspen suckers? J For 29:524-525.

Shirley HL. 1932. Does light burning stimulate aspen suckers? II. J For 30:419-20

Shugart HH. 1984. A theory of forest dynamics. New York: Springer-Verlag.

Stoeckeler J H. 1948. The growth of quaking aspen as affected by soil properties and fire. J For 46:727-37.

Stoeckeler JH, Macon J W. 1956. Regeneration of aspen cutover areas in northern Wisconsin. J For 54:13-6.

Tester J, Starfield A, Frelich LE. 1997. Modeling for ecosystem management in Minnesota pine forests. Biol Conserv 80: 313-24.

Thom R. 1975. Structural stability and morphogensis. Reading (MA): Benjamin.

Tubbs $\mathrm{CH}$. 1977. Age and structure of a northern hardwood selection forest. J For 75:22-4.

Turner MG, Romme WH, Gardner RH, Hargrove WW. 1997. Effects of fire size and pattern on early succession in Yellowstone National Park. Ecol Monogr 67:411-34.

Uhl C. 1987. Factors controlling succession following slash-andburn agriculture in Amazonia. J Ecol 75:377-407.

Uhl C, Clark K, Dezzeo N, Maquirino P. 1988. Vegetation dynamics in Amazonian treefall gaps. Ecology 69:751-63.

Van Wagner CE. 1978. Age class distribution and the forest fire cycle. Can J For Res 8:220-7.

Veblen TT, Stewart GH. 1982. On the conifer regeneration gap in New Zealand: the dynamics of Libocedrus bidwillii stands on South Island. J Ecol 70:413-36. 
Webb III T. 1987. The appearance and disappearance of major vegetational assemblages: long-term vegetational dynamics in eastern North America. Vegetatio 69:177-87.

Whelan RJ. 1995. The ecology of fire. Cambridge: Cambridge University Press.

Whitney GG. 1986. Relation of Michigan's presettlement pine forests to substrate and disturbance history. Ecology 67: 1548-59.

Whitney GG. 1987. An ecological history of the Great Lakes forest of Michigan. J Ecol 75:667-84.
Wilson JB, Agnew ADQ. 1992. Positive feedback switches in plant communities. Adv Ecol Res 23:263-336.

Yamamoto S-I. 1989. Gap dynamics in climax Fagus crenata forests. Bot Mag Tokyo 102:93-114.

Zeeman EC. 1976. Catastrophe theory. Sci Am 234:65-83.

Zehngraff PJ . 1949. Aspen as a forest crop in the Lake States. J For 47:555-65.

Zon R, Scholz HF. 1929. How fast do northern hardwoods grow? Washington (DC): US Department of Agriculture; Lake States Forest Experiment Station, Research Bulletin 88. 